\title{
Preferences (Attitudes and Preferences of Vegetables) of School Children Reviewed from knowledge
}

\author{
Ronasari Mahaji Putri*, Susmini, Neni Maemunah \\ Tribhuwana Tunggadewi University, Malang, East Java, Indonesia \\ putrirona@gmail.com
}

\begin{abstract}
ABSTRAK
Vegetables are one of the ingredients of food that should be part of the consumption of school children. However, in reality there are not many children who want to consume vegetables and fruits. The low consumption of vegetables and fruit in school children is due to multifactor. This study aims to determine the relationship of knowledge with preference (attitudes and preferences of vegetables). The design of the observational study using a cross sectional design was carried out in November 2018. The population in this study were all children found in Yayasan Eleos Sukodadi Village, Wagir Sub-District, Malang Regency, with 57 children, with total sampling. Independent variables are children's knowledge, with dependent variables being prefence (attitude and preference) of vegetables. The instrument uses 3 questionnaires with a total of 34 questions. Analysis of data to determine the relationship between preference knowledge (preferences and attitudes) of vegetables and fruit using rank spearman test and SPSS Version 17. The results of the study show that most school children have sufficient knowledge $(63,2 \%)$ and half of the respondents have good preferences $(50.9 \%)$. The statistical test showed that there was no relationship between knowledge and vegetable preferences in school children.
\end{abstract}

Keywords: Attitude, Knowledge, Preference, School Children, Vegetable 


\section{STRADA Jurnal Ilmiah Kesehatan}

DOI: $10.30994 /$ sjik.v9i1.233

ISSN: 2252-3847 (print); 2614-350X (online)

Vol.9 No.1. May 2020. Page.147-161

\section{INTRODUCTION}

School period is one age group that is experiencing a period of rapid growth and development. In this age group the fulfillment of nutrients both micro and macro is very important. Fulfillment of child nutrition well in terms of quality and quantity will greatly support physical growth and development of the child's organs. According to Xinhua News Agency - CEIS (2005) nutrition is very important early in life because it is in the age of early childhood development and then leads to a positive economic impact through increasing productivity in adolescence and adulthood.

Vegetables are one of the ingredients of food that should be part of the eating consumption of school children. Regular combination of vegetables and fruits in the consumption of children's food, will make the child's body healthy, have active movements, and have good immune system so that they are not easily sick. Research Canter, Roberts, \& Davis (2017) of 148 elementary school children whose parents have low income, it is found that children with consumption of vegetables and fruits that are in accordance with the recommended portion will be more physically and more active than children who consume less vegetables and fruits

It is not an easy matter to invite children in school age to have a habit of consuming vegetables and fruits regularly. The phenomenon of the low consumption of vegetables and fruit in school children is still not resolved. Various studies have found more consumption of vegetables and fruits of children with a portion that is less than the recommended portion of the USDA (Epstein et al. (2001); Gross, Pollock, \& Braun (2010); Guenther, Dodd, Reedy, \& Krebs-smith, (2006); Horne et al., (2004); Maddison R, Turley M, Legge N, (2010); Vereecken CA, Damme WV (2005); As many as 75\% of preschool children consume less fruits and vegetables than are recommended for children's health (Hong, Bales, \& Wallinga, 2018).

In Indonesia, this condition is not much different. 2013 Riskesdas revealed that the average consumption of vegetables in Indonesian people was $63.3 \%$ and for fruits $62.1 \%$ than recommended. It can be stated that these two percentages are far from the recommended consumption needs. The Ministry of Health (2014) also confirmed that $93.5 \%$ at the age of more than 10 years consume fruit and vegetables below the recommended amount of consumption; the low consumption of vegetables and fruits is evenly distributed in all age groups in rural and urban areas, and the lowest in the teen age group (98.4\%).

If studied further, there are many factors that affect the low consumption of vegetables and fruits in school children. One of them is socio-economic factors. Low socio-economics will reduce the family's purchasing power of vegetables and fruit. With families having low purchasing power, vegetables and fruits have little chance to be bought and become family consumption. The statement is in line with the results of research which state that children with less socioeconomic conditions are less likely to consume fruits and vegetables compared to peers who have higher socioeconomic conditions (Rasmussen et al., 2006 ; Granner et al., 2004)

The low consumption of vegetables and fruit in these children, need to be followed up immediately because children are in a period of rapid growth and development and begin to develop eating habits in childhood. Wardle et al., (2003); Godrich, Davies, Darby, \& Devine (2018) revealed that to overcome the lack of vegetables and fruit in children it needs to be done as early as possible, because these habits are formed from childhood and tend to be brought to adult life. The quality of one's food will have a large impact on the overall health of adolescents. Keep in mind that vegetables and fruits are very good 


\section{STRADA Jurnal Ilmiah Kesehatan}

DOI: $10.30994 /$ sjik.v9i1.233

ISSN: 2252-3847 (print); 2614-350X (online)

Vol.9 No.1. May 2020. Page.147-161

consumption ingredients for health, besides they also contain nutritional elements of vitamins and minerals that are needed by the body. The lack of vegetable intake and fruit has a negative impact on health. Agree with Munoz, Krebs-Smith, Ballard-Barbash, \& Cleveland (2004);Edwards, J S A; Hartwell (2002) which states that foods such as vegetables and fruits support bone health and reduce the risk of coronary heart disease and cancer. Even WHO (2012) also states that the low intake of vegetables and fruit is one of the ten main risk factors that cause death, including $2.8 \%$ of deaths due to low consumption of vegetables and fruit. But unfortunately, not many people want to prevent disease through the consumption of vegetables and fruits at a young age (Søndergaard \& Edelenbos, 2012)

Various educational activities and health promotions about the importance of vegetables have been sought, but still have not shown satisfactory results. Continuous and continuous promotion programs are needed to get maximum results. Health education and promotion is provided with the aim of all relevant parties, including in this case also in elementary school children. Promotional activities related to healthy lifestyles in elementary school children are expected to be able to increase children's knowledge, especially the behavior of consuming vegetables and fruits, and provide better attitude changes and behavior changes than before. Regular consumption of vegetables and fruit will make the child physically healthy, and make children more active. Physical activity is significantly related to the intake of vegetables and fruit of children (Canter et al., 2017). RM Putri; V Silalahi; NL Ariani (2019) research shows that there is an improvement in vitamin C intake in the consumption of vegetables / fruits of children after the health education for teachers.

Vegetable and fruit consumption behavior in children is strongly influenced by children's knowledge of the importance of vegetables. The number of children who have low knowledge about vegetables. Khatima H., Jafar.,N., Salam A.(2015) found less knowledgeable students. about vegetables by 49.1\%. Supported Putri, RM., Maemunah (2017) who received less knowledge of vegetable types at $83.7 \%$ of children, knowledge of the benefits of vegetables that was less than $55.1 \%$, and a number of $69.4 \%$ did not know how to consume less vegetables.; Putri, Susmini, \& Hadi (2017) revealed that at Yayasan Eleos, Sukodadi Village, Wagir Sub-District, Malang Regency showed that most of the knowledge of children aged 5-12 years about the types, benefits, content and consequences of vegetable deficiencies were in the less category. Knowledge about vegetables here has a very important role, because with good vegetable knowledge it will also have a positive impact on attitudes and is expected to also impact on good and quality vegetable and fruit behavior. On the other hand, knowledge of vegetables that is lacking, causes school children not to know or even understand the benefits of consuming fruits and vegetables for the body. Lack of knowledge will reduce the interest of school children to just try vegetable or fruit flavors.

And it is suspected by researchers that this child's knowledge is related to vegetable and fruit preferences. Preference is a form of vegetable acceptance which includes the attitudes and preferences of children. Many children do not like vegetables, and even openly refuse to consume vegetables. Various behaviors that show resistance when told to consume vegetables such as shutting up and spontaneously say no to vegetables. This researcher's statement is in accordance with Fildes, Van Jaarsveld, Wardle, \& Cooke (2014); Remington, Añez, Croker, Wardle, \& Cooke (2012) which states that the preference of children for vegetables is very low, and tends to refuse to consume vegetables. Penelitian Leuven, Rutenfrans, Dolfing, \& Leuven, (2018) study found that $10 \%$ of children 


\section{STRADA Jurnal Ilmiah Kesehatan}

DOI: $10.30994 /$ sjik.v9i1.233

ISSN: 2252-3847 (print); 2614-350X (online)

Vol.9 No.1. May 2020. Page.147-161

worldwide had been diagnosed with excessive weight, with the cause being a low vegetable intake and preference for vegetables, fruit. In line with Khatima H., Jafar., N., (2015) who found $49.7 \%$ of students in SMP 1 Kesu 'North Toraja district had a preference not to like vegetables and fruit, and gave a negative attitude towards vegetables by $44.4 \%$. This study also revealed a lack of connection between knowledge and preferences with the consumption of vegetables and fruit; and there is a relationship between attitude and consumption of vegetables and fruit. To increase children's preference for vegetables, it takes a lot of effort from various parties.Leuven et al. (2018) revealed that gardening in schools significantly increases the knowledge of elementary school children about 10 vegetables and increases short-term / long-term preferences for some vegetables to increase.

This research is a follow-up study, where previously there were problems with lack of vegetable knowledge in the children of Yayasan Eleos Sukodadi Village, Wagir District, Malang Regency.

\section{METHODS}

The observational study with a cross sectional design was carried out in November 2018. The population in this study were all children found at Yayasan Eleos Sukodadi Village, Wagir Sub-District, Malang Regency, with 57 children, with total sampling. Independent variables are children's knowledge, with dependent variables being prefence (attitude and preference) of vegetables. Instruments using 3 questionnaires with a total of 34 questions, namely knowledge questionnaire (16 questions), favorite vegetables ( 8 vegetables) and attitude towards vegetables (10 questions). Data analysis to determine the relationship between preference knowledge (preferences and attitudes) of vegetables using the rank spearman test and SPSS version 17.

\section{RESULTS}

Table 1. Characteristics of Respondents in General

\begin{tabular}{lll}
\hline Variabel & Amount & \% \\
\hline Gender & 21 & 36,8 \\
Man & 36 & 63,2 \\
Women & & \\
\hline Age group & 23 & 40,4 \\
\hline 5-11 age & 32 & 56,1 \\
$12-16$ age & 2 & 3,6 \\
17-25 age & & \\
\hline Father's education & 1 & 1,8 \\
\hline Bachelor & 10 & 17,5 \\
High school & 28 & 49,1 \\
Junior High School & 17 & 29,8 \\
Elementary School & 1 & 1,8 \\
No school & & \\
\hline Mother's school & 9 & 15,8 \\
\hline High school & 31 & 54,4 \\
Junior High School & 14 & 24,6 \\
Elementary School & &
\end{tabular}




\section{STRADA Jurnal Ilmiah Kesehatan}

DOI: $10.30994 /$ sjik.v9i1.233

ISSN: 2252-3847 (print); 2614-350X (online)

Vol.9 No.1. May 2020. Page.147-161

\begin{tabular}{lll}
\hline No school & 3 & 5,3 \\
\hline Father's job & & \\
\hline Building & 8 & 14 \\
Private & 32 & 56,1 \\
Farmer & 17 & 29,8 \\
\hline Mother's job & \\
\hline RT Assistant & 3 & 5,3 \\
IRT & 17 & 29,8 \\
Farmer & 11 & 19,3 \\
Privat & 24 & 42,1 \\
Nurse & 2 & 3,5 \\
\hline ownership of information source (amount) \\
\hline 1 & 16 & 28,1 \\
2 & 24 & 42,1 \\
3 & 11 & 19,3 \\
4 & 6 & 10,5 \\
\hline
\end{tabular}

Table 1 shows most of the respondents were female, $36(63.2 \%) ; 32$ respondents $(56.1 \%)$ were in the age group of early adolescents (12-16 years); 28 fathers of respondents $(49.1 \%)$ had junior high school education; 31 respondents $(54.5 \%)$ had junior high school education; 32 fathers of respondents $(56.1 \%)$ worked privately; 17 respondents $(29.8 \%)$ did not work (IRT); as many as 24 respondents (42,\%) had ownership of 2 types of information sources, namely television and handphone (cellphone).

Table 2. Characteristics of Respondents Based on Family Vegetable Consumption Management

\begin{tabular}{lcc}
\hline Variable & Amount & $\%$ \\
\hline Availability of vegetables & & \\
Selalu & 29 & 50,9 \\
Jarang & 27 & 47,4 \\
Tidak pernah & 1 & 1,8 \\
\hline \multicolumn{2}{l}{ Assistance in eating vegetables } & \\
\hline Always & 16 & 28,1 \\
Sometimes & 36 & 63,2 \\
Never & 5 & 8,8 \\
\hline Exemplary vegetable consumption & \\
\hline Always & 25 & 43,9 \\
Sometimes & 27 & 47,4 \\
Never & 5 & 8,8 \\
\hline the role of friends & & \\
\hline Always & 13 & 22,8 \\
Sometimes & 36 & 63,2 \\
Never & 8 & 14 \\
\hline Provision of vegetables by schools & \\
\hline Always & 2 & 3,5 \\
Sometimes & 13 & 22,8 \\
Never & 42 & 73,7 \\
\hline
\end{tabular}




\section{STRADA Jurnal Ilmiah Kesehatan}

DOI: $10.30994 /$ sjik.v9i1.233

Table 2 shows that most of the 29 families of the respondents (50.9\%) always provided vegetables when pickled eating at home; 36 families of respondents $(63.2 \%)$ sometimes accompanied children when eating vegetables at home; as many as 27 families of respondents $(47.4 \%)$ sometimes gave examples / examples of consuming vegetables when at home; 36 respondents (63.2) sometimes saw friends consuming vegetables at home (the role of friends); and as many as 42 respondents (73.7\%) said they never got vegetables from the school.

Table 3. Frequency Distribution Based on Respondents' Knowledge, Attitudes and Preferences

\begin{tabular}{lll}
\hline Variable & Amount & $\%$ \\
\hline Knowledge & & \\
Well & 16 & 28,1 \\
Enough & 36 & 63,2 \\
Less & 5 & 8,8 \\
\hline Attitude & & \\
\hline Well & 38 & 66,7 \\
Enough & 19 & 33,3 \\
Fondness & & \\
\hline Well & 27 & 47,4 \\
enough & 29 & 50,9 \\
Less & 1 & 1,8 \\
vegetable preferences & & \\
Well & 29 & 50,9 \\
Enough & 28 & 49,1 \\
\hline
\end{tabular}

Table 3 shows that 36 respondents $(63.2 \%)$ had sufficient knowledge about vegetables; 38 respondents $(66.7 \%)$ had a good attitude about vegetable consumption; 29 respondents $(50.9 \%)$ had a favorite level of vegetables in the sufficient category; 29 respondents $(50.9 \%)$ had vegetable preferences in good categories.

Table 4. Test Statistics on Relationship of Knowledge with Vegetable Preferences

\begin{tabular}{lll}
\hline Spearman's rho & Fondness & Attitude \\
\hline Knowledge & 0,246 & 0,221 \\
\hline & Preference & \\
Knowledge & 0,086 & \\
\hline
\end{tabular}

Table 4 shows the results of statistical tests using spearman rho obtained $\mathrm{p}$ value 0.086 . This data shows that there is no relationship between vegetable preference knowledge in school children in the Yayasan Eleos Sukodadi Village, Wagir Sub-District, Malang Regency

\section{DISCUSSION}

\section{Respondent Knowledge}

Most respondents have enough knowledge about the importance of vegetables. The results of this study indicate that respondents know enough and understand the importance of vegetables for health. Knowledge of respondents in the category is due to many factors, one of which is education. Most of the respondents were in the group of junior high school 


\section{STRADA Jurnal Ilmiah Kesehatan}

DOI: $10.30994 /$ sjik.v9i1.233

ISSN: 2252-3847 (print); 2614-350X (online)

Vol.9 No.1. May 2020. Page.147-161

students. A small part is in the lower level of education, namely elementary school education. Junior high school education is the level of basic education found in formal education after being declared graduated from elementary school / equivalent. So it can be said at this level that the students' thinking will be opened to the real knowledge.Included in the importance of vegetables. At this level, students are thought to be still in the stage of knowing and starting to enter the stage of understanding the importance of vegetables. Students begin to learn to receive information scientifically through school. With the existence of formal education provided regularly, it is possible that more knowledge will be entered into the respondents. During formal education, knowledge is obtained by students from many sources. Including knowledge gained from mass media, and parents. With the increasing amount of knowledge coming from various sources, it will be easier for someone to receive information about an object (Notoatmodjo, 2010). The level of education contributes to children's knowledge.

Agree with the results of the research of Franchini, B., Poínhos, R., Klepp, K., \& Almeida (2013) in Portugal that it was conveyed that Portuguese mothers who had higher levels of education showed higher daily vegetable intake compared to them who have less than 7 years of education ( $\mathrm{p}=0.007$ for $10-12$ years and education more than 12 years). If it is related to this theme, mothers who consciously consume vegetables and fruits have higher degrees of education than those with less education. With mothers having the habit of consuming vegetables and fruits with the quality and quantity in accordance with the instructions, the child will be moved to follow the habits of the mother. Through the principles of exemplary from parents, it will also have an impact on the formation of vegetable consumption habits in children. The study also found a combination of vegetable and fruit consumption between classes IV and V compared to class VI-VIII, with the highest intake in higher grade classes. The results of this study concluded by researchers that there might be an increase in knowledge along with the increasing level of education. A person will not consume vegetables and fruit, before knowing that this type of food is very beneficial for the health of the body. Overall the level of education, social class and area of residence did not show a significant relationship with daily intake of fruits and vegetables. However, the education level shows a positive and significant relationship with a combination of daily fruit and vegetable intake among Portuguese mothers who are included in the higher education level category (education 10-12 years; $p=0.031$ ) when compared to less than 7 years education(Franchini, B., Poínhos, R., Klepp, K., \& Almeida, 2013).

Knowledge of school children that is sufficient about the importance of vegetable consumption is also influenced by experience factors. Experience is one of the valuable things that also determines the emergence of knowledge. A person's experience greatly influences the formation of knowledge, with someone's experience of something, it will increase one's knowledge of it. Included also in relation to the importance of knowledge of vegetable and fruit consumption. School children who have consumed vegetables and fruit will have their own knowledge through their senses

Repetition of consumption after the first consumption is strongly influenced by the acceptance and interest in the taste and aroma of vegetables, fruit.(Dresler, Whitehead, \& Mather (2017) conducted a study of 36 boys and girls in the Manawatu Region of New Zealand, who said that children who have been exposed to vegetables and fruit (have consumed vegetables and fruit) will again consume vegetables or fruit depending on the factors of appreciation and the risk obtained from consumption of this type of food.The 


\section{STRADA Jurnal Ilmiah Kesehatan}

DOI: $10.30994 /$ sjik.v9i1.233

results of this study also found that children know and understand the importance of vegetables for the body, but for consumption of ayur and fruit then depends on the risks felt by children (related to children's sensory).Sensory children who prefer sweetness, make children tend to avoid strategies if they have to consume vegetables. Children who are often given vegetables and fruit on a regular basis, with a frequency that is relatively frequent so that almost becoming a habit at home will also increase the acceptance of vegetables and fruit in children. In accordance with Morris JL, Neustadter A (2001);O'Brien SA (2006); Poston SA, Shoemaker CA, (2005) which revealed that the number of opportunities for taste testing, vegetable or fruit preferences at the start, sample size, and duration of interventions can all influence children's vegetble and fruit taste preferences as a result of school nutrition interventions.

Another factor that influences respondents' knowledge in a sufficient category is one of them is gender. Most of the respondents are female. Women are different from men in knowing their nutritional needs. Women tend to pay more attention and care about health than men. Included in the fulfillment of vegetables and fruits at meals.. Pollard, etc (2009) stated that overall women were more likely to know the recommended vegetable intake compared to men $(\mathrm{p}<0.001)$. However, the results of this study showed that there was no significant difference between the proportion of women and men correctly in identify the minimum recommended fruit intake.

Another factor that influences knowledge is age. Most respondents are in the 12-16 year age group. The age of 12-16 years is included in the age category of psychic development. The more people grow older, one can say that they will experience development and experience significant changes. The changes here referred to are the development of maturity in the thought process, and a more mature psychic. Rahayu Sri Ani, (2010) revealed that the increasing age of a person can make changes to physical, psychological, and psychological aspects. In the psychological aspects of a person's level of thinking is more mature and mature.

Sufficient knowledge on respondents is also influenced by interest. The interest in this discussion is the interest to consume vegetables. Interest is a tendency in the heart that is able to move someone to do or consume something because of a strong urge in themselves. By passing this interest, knowledge will be formed with what is based on the factor of trying something. Agree with Rahayu Sri Ani, (2010) which states that interest is a form of desire and interest in something. Interest makes someone to try and pursue something and in the end can get more in-depth knowledge. If studied from the results of knowledge that falls into sufficient category this, it is possible for children to consume less vegetables and fruits. Unwilling to try to consume vegetables and fruit makes children less able to know and understand vegetables and fruit.

Knowledge is also influenced by the media. Most of the respondent's families have 2 communication media namely cellphone and television. This media is very important to be able to help launch messages or information to the community with the aim of being affected and interested in doing / consuming something that is displayed on social media. Examples of media specifically designed to reach the wider community such as television, radio, newspapers, magazines and the internet (Rahayu Sri Ani, 2010). Information as a technique for collecting, preparing, and storing, manipulating, announcing, analyzing, and disseminating information with specific purposes and objectives that can be obtained through electronic and printed media (Rahayu Sri Ani, 2010). 


\section{STRADA Jurnal Ilmiah Kesehatan}

DOI: $10.30994 /$ sjik.v9i1.233

ISSN: 2252-3847 (print); 2614-350X (online)

Vol.9 No.1. May 2020. Page.147-161

Children's knowledge about vegetables and fruit is also influenced by the involvement of the school. The role of the school is very helpful in improving students' knowledge. Various knowledge is obtained during school. The school in question here is the teachers at the school. All school activities have a good influence on students, including food consumption. The results of the study show that the gardening program in schools increases the knowledge of vegetables and fruit in school children. As many as $98.5 \%$ of children were able to mention 5 vegetables and fruits, with the kind that became the favorite of children is apples, bananas, carrots, oranges and strawberries (Hanbazaza MSc et al., 2015).

Student are educated by the school to have good eating habits, and can develop eating well. The lunch activity provided by the school contains a healthy menu consisting of rice, side dishes and vegetables making students have good eating habits. Feeding activities supervised by homeroom teachers, making students who may have been forced to consume vegetables, become accustomed to consuming vegetables.. Burghardt J, Gordon A, Chapman N, Gleason P (1993) which states that the school environment helps someone to make changes positive for diet (Burghardt J, Gordon A, Chapman N, Gleason P, 1993). Research shows that companies that have promoted healthy lifestyles to protect the health of employees, indicate a return of positive incestations, namely increased performance. The study also found a possible relationship between food and performance (Burghardt $\mathbf{J}$, Gordon A, Chapman N, Gleason P (1993); Mills, P.R., Kessler, R.C., Cooper, J. and Sullivan (2007). It takes the role of educational promotion to be able to improve children's knowledge, in accordance with V Silalahi; RM Putri; Ariani NL (2018) which revealed that there were differences in fruit intake for students after nutrition education to school teachers.

\section{Preference Sayur}

Preference Most respondents have vegetable preferences in good categories. The results of this study indicate that the preference of elementary school children at the Eeleos Wagir Foundation is in the appropriate category expected. This good vegetable preference is obtained from the combination of attitudes and preferences of vegetables. From the results of this study illustrated that the attitude of school children about vegetables in a good category, however, for children's preference for vegetables in the category is enough.

Most families of children, provide vegetables and fruit. However, almost half the other families rarely provide vegetables and fruit at home. Most families of children do not accompany children when consuming vegetables and fruits. From this data raises doubts whether children consume vegetables and fruits provided by the family? Children basically know that consumption of vegetables and fruit is important to them. Children will consume food provided by their parents at home. However, the factor of eating assistance also plays an important role in the success of eating fruits and vegetables for children. The availability of vegetables and fruits at this house is one of the important parts in the consumption of children, which turns out to also be able to have an impact to bring out the children's preference for vegetables and fruit. Karena selalu terpapar dengan buah dan sayur maka akan muncul preferensi yang baik pada anak tentang jenis makanan tersebut. Heim, Stang, \& Ireland (2009) state that children tend to consume foods that are available regularly for them, which means that exposure to fruit and vegetables early in life can affect children's future consumption by increasing their preferences and preferences for food. this. With parents always providing vegetables and fruit at home will also help instill 


\section{STRADA Jurnal Ilmiah Kesehatan}

DOI: $10.30994 /$ sjik.v9i1.233

ISSN: 2252-3847 (print); 2614-350X (online)

Vol.9 No.1. May 2020. Page.147-161

vegetable eating habits later on. The taste preferences for $\mathrm{V} \& \mathrm{~F}$ developed in childhood can continue throughout life (Lien N, Lytle LA ( 2001); Kelder SH, Perry CL, Klepp KI, (1994)

The school environment is one of the most prospective environments to help change children's behavior. School interventions that focus on increasing vegetable and fruit consumption through increased exposure may be an effective approach to improving the quality of children's food and reducing the risk of chronic diseases. As an example of lunch activities held in schools, it would be very helpful to increase children's eating preferences. School environments can help promote changes in positive eating patterns (Burghardt J, Gordon A, Chapman N, Gleason P, 1993).

Other research results also show that school activities such as gardening and snacking programs in schools increase preference and consumption of vegetables and fruit in school children (Lautenschlager \& Smith, 2007; Hermann JR, Parker SP, Brown BJ, Siewe YK, Denney BA, 2006). The researcher also said that this 18-month program increased fruit preference scores for children, and for vegetables there was an increase in preference 7 months after the intervention intervention declined to near the level at the beginning of 18 months. The findings also show that foods that are liked and disliked by children are the most frequent and most consumed foods by children while at home (Hanbazaza MSc et al., 2015) and increase the acceptance of vegetables and fruits (Morris JL, Neustadter A, 2001; Cason KL, 2002; Lineberger \& Zajicek, 2000))

We all know that children love sweetness. From this reason there is also an understanding that why children prefer fruit over vegetables. Children prefer sweetness as found in fruit compared to the bitter taste found in vegetables (Anzman-Frasca, Savage, Marini, Fisher, $\&$ Birch, 2012). This taste preference for sweetness can partly explain why children do not consistently increase their vegetable preferences during an 18-month intervention even though there are many opportunities to taste vegetables. This lack of consistent preference for vegetables is problematic because several studies have shown that vegetable and fruit preferences, not just exposure and knowledge of vegetables and fruits, are significant predictors of fruit and vegetable consumption in children (Domel et al., 1996).

Increase the availability of Vegetables \& Fruits in schools, at home, and in the community; opportunities for repeated taste testing for children; involving children in taste-tasting activities; family involvement in activities that promote healthy eating at home; explain to parents about the importance of a good nutrition role model; and involving children in direct activities with their peers such as planting and harvesting vegetables and fruit, all of which can be a strategy to increase children's vegetable and fruit intake and help children develop permanent healthy eating habits(Hanbazaza MSc et al., 2015)

\section{KNOWLEDGE AND VEGETABLE PREFERENCE, FRUIT}

The results of statistical tests showed that there was no relationship between vegetable knowledge (preference and preference) in school children at Eleos Wagir Foundation. There was no correlation between knowledge and preference of vegetables in children because the role of vegetable and fruit availability at home was more dominant in relation to preference of vegetables compared to the knowledge of children. Parents who have a habit of providing vegetables and fruit for the family, and can ensure that their family members consume dishes prepared by parents, then over time the child will have a preference for vegetables and fruit. Children tend to choose to consume foods that they serve regularly, and they tend to choose to eat foods available at home (C. et al., 2007). 


\section{STRADA Jurnal Ilmiah Kesehatan}

DOI: $10.30994 /$ sjik.v9i1.233

ISSN: 2252-3847 (print); 2614-350X (online)

Vol.9 No.1. May 2020. Page.147-161

Young et al. (2013) that school children consume fewer vegetables than fruit consumption $(\mathrm{p}<0,0001)$. Although in this study the preference of vegetables and fruits was in the good category, it was still necessary to establish self-concept in children through continuous self-motivation in order to want to consume vegetables and fruits, and continue to be built so as to increase consumption of vegetables and fruits (Albani et al., 2018).

Consumption of eating healthy and unhealthy children is influenced by the power of decisions taken by parents and the availability (supporting factors), as well as strengthening of mothers to provide healthy food and also peer strengthening not to consume unhealthy foods. The results showed that most of the respondents' parents accompanied them to eat vegetables and fruit in rare categories, and almost half of the respondents gave examples of consuming vegetables / fruits while at home. This data shows a discrepancy with the theory of Larson \& Story (2009); Savage JS, Fisher JO, (2007) which reveals that parents are responsible for buying, preparing, and making food available for children and becoming role models for healthy eating; Therefore, they can have a greater impact on children's food preferences, which consequently can affect food preferences for life. Parents are expected to not only provide healthy food, but also provide assistance and role models / examples in consuming fruits and vegetables for their children.

Regarding the availability of vegetables and fruits, not all mothers are able to provide vegetables and fruits every day due to the high cost of fruit. With high financing needs for fulfilling consumption of vegetables and fruits, it is possible for families to experience food insecurity in the household and the lack of physical access for children to healthy food. The impact of this limitation is family difficulties in preparing high-quality food for children (Findlay LC, Langlois KA, 2013;(Willows ND, Veugelers P, Raine K, 2009); revealing that low consumption of vegetables and fruits at home can be a result from household food insecurity and lack of physical access to healthy food Financial constraints coupled with high costs and limited availability of nutritious food in many indigenous communities can make it difficult for families to provide high-quality food for their children(Huet C, Rosol R, 2012; Egeland, Pacey, Cao, \& Sobol, 2010)

\section{CONCLUSION}

Most of the vegetable knowledge of school children is in the sufficient category

Half of the respondents have vegetable preferences, each in a good, and sufficient category There is no relationship between knowledge with preferences (attitudes and preferences) of children's vegetables in the Yayasan Eleos Sukodadi Village, Wagir Sub-District, Malang Regency

\section{REFERENCES}

Anzman-Frasca, S., Savage, J. S., Marini, M. E., Fisher, J. O., \& Birch, L. L. (2012). Repeated exposure and associative conditioning promote preschool children's liking of vegetables. Appetite, 58(2), 543-553. https://doi.org/10.1016/j.appet.2011.11.012

Burghardt J, Gordon A, Chapman N, Gleason P, F. T. (1993). The school nutrition dietary assessment study: school food service, meals offered, and dietary intakes.

C., A., D., N.-S., P., H., P., V. D. B., M., S., N., L., ... Larson, N. (2007). Parental eating behaviours, home food environment and adolescent intakes of fruits, vegetables and dairy foods: Longitudinal findings from Project EAT. Public Health Nutrition, 10(1111257-65). https://doi.org/10.1017/S1368980007687151 


\section{STRADA Jurnal Ilmiah Kesehatan}

DOI: $10.30994 /$ sjik.v9i1.233

ISSN: 2252-3847 (print); 2614-350X (online)

Vol.9 No.1. May 2020. Page.147-161

Canter, K. S., Roberts, M. C., \& Davis, A. M. (2017). The role of health behaviors and food insecurity in predicting fruit and vegetable intake in low-income children. Children's Health Care, 46(2), 131-150. https://doi.org/10.1080/02739615.2015.1124772

Cason KL. (2002). Children are "growing healthy" in South Carolina. J Nutr Educ, 31(4), 235. https://doi.org/10.1016/S0022-3182(99)70446-2

Domel, S. B., Thompson, W. O., Davis, H. C., Baranowski, T., Leonard, S. B., \& Baranowski, J. (1996). Psychosocial predictors of fruit and vegetable consumption among elementary school children. Health Education Research, 11(3), 299-308. https://doi.org/10.1093/her/11.3.299

Dresler, E., Whitehead, D., \& Mather, A. (2017). The experiences of New Zealand-based children in consuming fruits and vegetables. Health Education, 117(3), 297-309. https://doi.org/10.1108/HE-08-2016-0032

Edwards, J S A; Hartwell, H. H. (2002). National Library of Medicine.Journal of human nutrition and dietetics. The Official Journal of the British Dietetic Association, 15(5), 365-374.

Egeland, G. M., Pacey, A., Cao, Z., \& Sobol, I. (2010). Food insecurity among inuit preschoolers: Nunavut inuit child health survey, 2007-2008. CMAJ, 182(3), 243-248. https://doi.org/10.1503/cmaj.091297

Epstein, L. H., Gordy, C. C., Raynor, H. A., Beddome, M., Kilanowski, C. K., \& Paluch, R. (2001). Increasing fruit and vegetable intake and decreasing fat and sugar intake in families at risk for Childhood Obesity. Obesity Research, 9(3), 171-178. https://doi.org/10.1038/oby.2001.18

Fildes, A., Van Jaarsveld, C. H. M., Wardle, J., \& Cooke, L. (2014). Parent-administered exposure to increase children's vegetable acceptance: A randomized controlled trial. Journal of the Academy of Nutrition and Dietetics, 114(6), 881-888. https://doi.org/10.1016/j.jand.2013.07.040

Findlay LC, Langlois KA, K. DE. (2013). Hunger among Inuit children in Canada. . . Int J Circumpolar Health, 72, 20324. https://doi.org/10.3402/ijch.v72i0.20324

Franchini, B., Poínhos, R., Klepp, K., \& Almeida, V. D. (2013). Fruit and vegetables: Intake and sociodemographic determinants among portuguese mothers. Annals of Nutrition \& Metabolism, 63(1-2), 131-138. https://doi.org/http://eresources.perpusnas.go.id:2130/10.1159/000351987

Godrich, S. L., Davies, C. R., Darby, J., \& Devine, A. (2018). Which ecological determinants influence Australian children's fruit and vegetable consumption? Health Promotion International, 33(2), 229-238. https://doi.org/10.1093/heapro/daw063

Granner, M. L., Sargent, R. G., Calderon, K. S., Hussey, J. R., Evans, A. E., \& Watkins, K. W. (2004). Factors of fruit and vegetable intake by race, gender, and age among young adolescents. Journal of Nutrition Education and Behavior, 36(4), 173-180. https://doi.org/10.1016/S1499-4046(06)60231-5

Gross, S. M., Pollock, E. D., \& Braun, B. (2010). Family influence: Key to fruit and vegetable consumption among fourth- and fifth-grade students. Journal of Nutrition Education and Behavior, 42(4), 235-241. https://doi.org/10.1016/j.jneb.2009.05.007

Guenther, P. M., Dodd, K. W., Reedy, J., \& Krebs-smith, S. M. (2006). Most Americans Eat Much Less than Recommended Amounts of Fruits and Vegetables Web site exclusive! $J$ Am Diet Assoc, 106(9), 1371-1379. https://doi.org/10.1016/j.jada.2006.06.002 


\section{STRADA Jurnal Ilmiah Kesehatan}

DOI: $10.30994 /$ sjik.v9i1.233

ISSN: 2252-3847 (print); 2614-350X (online)

Vol.9 No.1. May 2020. Page.147-161

Hanbazaza MSc, M. A., Triador MSc, L., Ball PhD, RD, G. D. C., Farmer PhD, RD, A., Maximova PhD, K., Nationd, A. F., ... Willows, N. D. (2015). The Impact of School Gardening on Cree Children's Knowledge and Attitudes toward Vegetables and Fruit. CANADIAN JOURNAL OF DIETETIC PRACTICE AND RESEARCH, 76(3), 133139. https://doi.org/10.3148/cjdpr-2015-007

Heim, S., Stang, J., \& Ireland, M. (2009). A Garden Pilot Project Enhances Fruit and Vegetable Consumption among Children. Journal of the American Dietetic Association. https://doi.org/10.1016/j.jada.2009.04.009

Hermann JR, Parker SP, Brown BJ, Siewe YK, Denney BA, W. S. (2006). After-school gardening improves children's reported vegetable intake and physical activity. $J$ Nutr Educ Behav, 38(3), 201-202.

Hong, J., Bales, D. W., \& Wallinga, C. R. (2018). Using Family Backpacks as a Tool to Involve Families in Teaching Young Children About Healthy Eating. Early Childhood Education Journal, 46(2), 209-221. https://doi.org/10.1007/s10643-0170848-8

Horne, P. J., Tapper, K., Lowe, C. F., Hardman, C. A., Jackson, M. C., \& Woolner, J. (2004). Increasing children's fruit and vegetable consumption: A peer-modelling and rewards-based intervention. European Journal of Clinical Nutrition, 58(12), 16491660. https://doi.org/10.1038/sj.ejcn.1602024

Huet C, Rosol R, E. G. (2012). The prevalence of food insecurity is high and the diet quality poor in Inuit communities. $J$ Nutr, 142(3), 541-547. https://doi.org/10.3945/jn.111.149278.

Kelder SH, Perry CL, Klepp KI, L. L. (1994). Longitudinal tracking of adolescent smoking, physical activity, and food choice behaviors. Am J Public Health, 84(7), 1121-1126. https://doi.org/: 10.2105/AJPH.84.7.1121

Khatima H., Jafar., N., S. A. (2015). Hubungan Perilaku dan Preferensi Dengan Konsumsi Sayur dan Buah Pada Remaja SMPN 1 Kesu' Kabupaten Toraja Utara. Retrieved from

http://repository.unhas.ac.id/bitstream/handle/123456789/12568/abstrak.pdf?sequenc $\mathrm{e}=1$

Larson, N., \& Story, M. (2009). A review of environmental influences on food choices. Annals of Behavioral Medicine. https://doi.org/10.1007/s12160-009-9120-9

Lautenschlager, L., \& Smith, C. (2007). Understanding gardening and dietary habits among youth garden program participants using the Theory of Planned Behavior. Appetite, 49(1), 122-130. https://doi.org/10.1016/j.appet.2007.01.002

Leuven, J. R. F. W., Rutenfrans, A. H. M., Dolfing, A. G., \& Leuven, R. S. E. W. (2018). School gardening increases knowledge of primary school children on edible plants and preference for vegetables. Food Science and Nutrition, 6(7), 1960-1967. https://doi.org/10.1002/fsn3.758

Lien N, Lytle LA, K. K. (2001). Stability in consumption of fruit, vegetables, and sugary foods in a cohort from age 14 to age 21. Prev Med, 33(3), 217-226.

Lineberger, S. E., \& Zajicek, J. M. (2000). School gardens: Can a hands-on teaching tool affect students' attitudes and behaviors regarding fruit and vegetables? HortTechnology, 10(3), 593-597.

Maddison R, Turley M, Legge N, et. a. (2010). A National Survey of Children and Young People's Physical Activity and Dietary Behaviours in New Zealand.

Mills, P.R., Kessler, R.C., Cooper, J. and Sullivan, S. (2007). No TitleImpact of a health 


\section{STRADA Jurnal Ilmiah Kesehatan}

DOI: $10.30994 /$ sjik.v9i1.233

ISSN: 2252-3847 (print); 2614-350X (online)

Vol.9 No.1. May 2020. Page.147-161

promotion program on employee health risks and work productivity. American Journal of Health Promotion, 22(1), 45-53.

Morris JL, Neustadter A, Z.-C. S. (2001). First-grade gardeners more likely to taste vegetables. California Agriculture, 55(1), 43-46. https://doi.org/10.3733/ca.v055n01p43

Munoz, K. A., Krebs-Smith, S. M., Ballard-Barbash, R., \& Cleveland, L. E. (2004). Food Intakes of US Children and Adolescents Compared With Recommendations. PEDIATRICS, 100(3), 323-329. https://doi.org/10.1542/peds.100.3.323

Notoatmodjo, S. (2010). Ilmu perilaku kesehatan. Jakarta: Rineka Cipta.

O’Brien SA, S. C. (2006). An after-school gardening club to promote fruit and vegetable consumption among fourth grade students: the assessment of social cognitive theory constructs. Horttechnology, 16(1), 24-29.

Pollard, Christina, MPH, G.CertP.SectMgt, G.DipDiet, Miller, Margaret, MAppSci, G.DipP.Adm, G.DipDiet, Woodman, Richard John, PhDMed, M.MedSci(Sport/Exc), M.B., Meng, R., M.AppE., \& Binns, Colin, MPH, MBBS, FRACGP, F.A.C.O.M., F. A. F. P. (2009). Changes in knowledge, beliefs, and behaviors related to fruit and vegetable consumption among western australian adults from 1995 to 2004. American Journal of Public Health, 99(2), 355-361.

Poston SA, Shoemaker CA, D. DA. (2005). A comparison of a gardening and nutrition program with a standard nutrition program in an outof-school setting. Horttechnology, 15(3), 463-467.

Putri, RM., Maemunah, N. (2017). PENGETAHUAN ANAK TENTANG PENTINGNYA SAYUR The Role of Education in Improving the Knowledge of Children about the Importance of Vegetables Asupan makanan yang bergizi memberikan manfaat yang sangat baik bagi pertumbuhan anak Makanan yang mengandung kalori. Jurnal Keperawatan, 8, 54-64.

Putri, R. M., Susmini, \& Hadi, H. S. (2017). GAMBARAN PENGETAHUAN SAYUR ANAK USIA 5-12 TAHUN DI YAYASAN ELEOS INDONESIA DESA SUKODADI KECAMATAN WAGIR KABUPATEN MALANG. Jurnal Ilmu Keperawatan, 5(1), 74-80. https://doi.org/https://doi.org/

Rahayu Sri Ani. (2010). Pengantar kebijakan Fiskal. Jakarta: Bumi Aksara.

Rasmussen, M., Krølner, R., Klepp, K., Lytle, L., Brug, J., Bere, E., \& Due, P. (2006). Determinants of fruit and vegetable consumption among children and adolescents: a review of the literature. Part I: quantitative studies. International Journal of Behavioral Nutrition and Physical Activity, 3(22). https://doi.org/10.1186/1479-58683-22

Remington, A., Añez, E., Croker, H., Wardle, J., \& Cooke, L. (2012). Increasing food acceptance in the home setting: A randomized controlled trial of parent-administered taste exposure with incentives. American Journal of Clinical Nutrition. https://doi.org/10.3945/ajcn.111.024596

RM Putri; V Silalahi; NL Ariani. (2019). PENDIDIKAN GIZI SEBAGAI SUATU UPAYA PEMENUHAN ZAT GIZI DARI SAYUR DAN BUAH PADA ANAK SEKOLAH DASAR. In Seminar Nasional 2018 " Peran Dan Tanggungjawab Tenaga Kesehatan Dalam Mendukung Program Kesehatan Nasional. Jember: Fakultas Ilmu Kesehatan Universitas Muhammadiyah Jember. https://doi.org/http://dx.doi.org/10.32528/psn.v0i0.1727

Savage JS, Fisher JO, B. L. (2007). Parental influence on eating behavior: conception to 


\section{STRADA Jurnal Ilmiah Kesehatan}

DOI: $10.30994 /$ sjik.v9i1.233

adolescence. J Law Med Ethics, 35(1), 22-34.

Søndergaard, H. A., \& Edelenbos, M. (2012). What parents prefer and children like Investigating choice of vegetable-based food for children. Food Quality and Preference, 18(7), 949-962. https://doi.org/10.1016/j.foodqual.2007.03.009

V Silalahi; RM Putri; Ariani NL. (2018). Peranan Pendidikan Gizi Pada Guru Dalam Meningkatkan Asupan Sayur Dan Buah Anak Sekolah. Care: Jurnal Ilmiah Ilmu Kesehatan, 6(3), 253-266. https://doi.org/http://dx.doi.org/10.33366/cr.v6i3.1039

Vereecken CA, Damme WV, M. L. (2005). Measuring attitudes, self-efficacy, and social and environmental influences on fruit and vegetable consumption of 11- and 12yearold children: reliability and validity. J Am Diet Assoc, 105, 257-261.

Wardle, J., Cooke, L. J., Gibson, E. L., Sapochnik, M., Sheiham, A., \& Lawson, M. (2003). Increasing children's acceptance of vegetables; a randomized trial of parentled exposure. Appetite, 40(2), 155-162. https://doi.org/10.1016/S01956663(02)00135-6

Willows ND, Veugelers P, Raine K, K. S. (2009). Prevalence and sociodemographic risk factors related to household food security in Aboriginal peoples in Canada. Public Health Nutrition, 12(8), 1150-1156. https://doi.org/10.1017/S1368980008004345

Xinhua News Agency - CEIS. (2005). Poor nutrition affects children's growth in cambodia. Retrieved from https://eresources.perpusnas.go.id:2082/docview/452784884?accountid=25704) 
STRADA Jurnal Ilmiah Kesehatan

DOI: $10.30994 /$ sjik.v9i1.233

ISSN: 2252-3847 (print); 2614-350X (online)

Vol.9 No.1. May 2020. Page.147-161 